\title{
YHTEISKUNNAN MUUTOSKIITO HAASTAA TYÖVÄENTUTKIMUKSEN
}

\author{
Hannu Itkonen \\ professori, Jyväskylän yliopisto
}

"Kulttuurisukupolvet varkautelaisissa työväenjärjestöissä” oli vuonna 1985 valmistuneen sosiologian pro gradu -tutkielmani otsikko. Tämän jälkeen olen ollut jollakin tavoin koko tutkijan urani ajan tekemisissä työväentutkimuksen parissa. Erityisesti olen tutkinut työläisurheilun muutoksia. Sosiologin peruskoulutuksen saaneena ja historiallista sosiologiaa tehneenä tutkijakatseeni on suuntautunut työväentutkimukseen laajemminkin.

Käsitteellisesti tarkasteltuna työväentutkimus on kohdentunut työväestöön ja sen tilanteen analysoimiseen. Lähtökohtaisesti olisikin hyödyllistä käydä tieteellistä ja miksei laajempaakin keskustelua työväen käsitteestä. Toki tällaisia pomilointeja harjoitetaankin. Pyrkimys työväenkulttuurin uusmäärittelyyn näkyy vaikkapa silmäiltäessä Työväen Musiikkitapahtuman ohjelman uudistumista.

Työväen ja työväestön suhteen on tehtävä käsitteellistä määrittelytyötä. Perinteisen työväestön ajat ovat kaukana historiassa. Pelkistetyimmillään yhtenäinen työväestö ja työväenluokka eli maailmansotien välisenä aikana omine elämäntapoineen ja kulttuureineen. Omissa tutkimuksissani olen nimennyt tämän aikakauden järjestökulttuurin kaudeksi, jolloin tärkeimpiä harrastustoiminnan tiloja olivat eri puolille Suomenniemeä rakennetut työväentalot.

Suomessa kuten monissa muissa maissa on viime aikoina keskusteltu uudenlaisen luokkayhteiskunnan muotoutumisesta. Göran Therborn osoittaa uudessa, suomeksikin kään- netyssä teoksessaan "Kadotettu kansankoti - Kuinka pääoma kaappasi Ruotsin", kuinka tasa-arvoisuuden mallimaasta on muokkautunut luokkayhteiskunta, jossa mitataan LänsiEuroopan korkeimpia pahoinvointilukuja. 1990-luvun laman jälkeen Suomessakin on ollut samankaltaisia muutospiirteitä, jotka antavat aihetta puhua uudenlaisesta luokkayhteiskunnasta.

Työväentutkimuksen haasteita pohdittaessa on väistämätöntä kyetä uudenlaiseen analyysiin ja eriytyneen yhteiskunnan käytäntöjen tutkimiseen. Omissa pohdinnoissani olen päätynyt seitsemään haasteeseen. Teema-alueita luonnostellessani olen hyvin tietoinen siitä, että kyseisiä ilmiöitä on tutkittu, osin jo perusteellisestikin.

Ensinnäkin, toimeentulon ja työelämän kysymyksiä tulisi tutkia uusista lähtökohdista. Niin sanotut "epätavanomaiset työsuhteet" alkavat olla kaikkea muuta kuin epätavanomaisia. Ilmiökokonaisuuden kimpussa riittäisi tekemistä. Aiheita olisivat etenkin prekarisaatio, pätkätyö, pienituloisuus, ihmisten selviytymistarinat ja pakkoyrittäjyys. Myös työelämän polarisaatio on edelleen ajankohtainen tutkimuskysymys.

Toinen kiinnostava tutkimuksen teemakokonaisuus löytyy poliittisesta päätöksenteosta, politiikkojen toiminnasta sekä ennen kaikkea siitä arvopohjasta ja ratkaisuista, joilla tähdätään tasa-arvoiseen yhteiskuntaan. Erityisen kiinnostava kysymys on työväenpuolueiden ja -järjestöjen toiminta paikallisina, alueellisina, valtakunnallisina ja kansainvälisinä vaikuttaji- 
na. Näyttää nimittäin siltä, että politiikan mediallistuminen ja somettuminen on jo muuttanut aiempia järjestökäytäntöjä. Erityinen haaste näyttääkin olevan, miten paikallistason järjestötoimintaa organisoidaan tulevaisuudessa. Tällöin kyse on myös uudenlaisista vaikuttamisen muodoista ja kansalaisaktiivisuudesta.

Kolmas haaste työväentutkimukselle nousee yleisestä polarisaatiosta, jossa osaa ihmisistä syrjäytetään yhteiskunnan ulkopuolelle. Useat tutkimukset osoittavat, kuinka esimerkiksi terveyserot ovat joiltakin osin jopa kasvaneet. Myös liikunnan ja kulttuurin harrastamisessa ilmenee sosio-ekonomisesta asemasta kumpuavaa eriarvoisuutta. Erityisesti tulisi tutkia perheköyhyyttä ja siihen liittyvää lasten ja nuorten huono-osaisuutta. Toki kaikista ikäluokista löytyy omat syrjäytetyt, joiden aseman kohentaminen edellyttää myös tutkijoiden tekemisiä.

Neljänneksi tutkimusteemaksi nostaisin työväenkulttuurin perinteiset ja uudet muodot. Vaikka monet nuorison tuottamat kulttuurituotteet eivät ehkä luokitukaan työväenkulttuuriksi, on niissä samanlaisia aineksia ja samanlaista tavoitteellisuutta kuin tasa-arvoon tähtäävässä työväenkulttuurissa. Juuri tämän jatkuvuuden tutkiminen olisi paitsi kiinnostava myös haastava tehtävä. Aiheen tutkimiselle antaa pontta se, että poliittisen vaikuttamisen menetelmät muuttavat alati muotoaan. Voidaan jopa kysyä, onko tällä hetkellä käynnissä jonkinlainen uusi arvokumous, jolle antavat vauhtia ympäristökysymykset ja aiempaa globaalimpi tapa ajatella myös muita yhteiskunnallisia ilmiöitä.

Viidenneksi, työväenjärjestöjen tutkimisessa riittää vielä runsaasti tekemistä. Vaikka työväenhistoriaa ja -perinnettä on tutkittu runsaasti, uusia tutkimusaukkoja löytyy koko ajan. Työväen historian ja perinteen tutkimuksen seuran järjestämät seminaarit nostavat esiin jatkuvasti sekä uusia tutkimusteemoja että kyvykkäitä nuoria tutkijoita. Työväenliikkeen historiaa jäljitettäessä tutkittavaa löytyy edelleen järjestötalojen käytännöistä, työväenjärjestöjen taloudesta, säätiöistä ja opinahjoista. Erityisen haasteellista olisi jäljittää paikallistason kokemuksellisuutta, mikä edellyttää monimenetelmällistä ja -aineistollista tutkimusotetta. Vertaileva tutkimusote muiden maiden työväenjärjestöjen toimintoihin on suurelta osin vielä kyntämätön pelto.

Kuudes haaste - ja jopa tutkimushankkeen itu - olisi työväenliikkeen tutkimushistorian kirjoittaminen. Työväen historian ja perinteen tutkimuksen seuran 30-vuotisjuhlakirjassahan useat tutkijat avasivat omalta osaltaan kaikkea sitä, mitä aihepiirin osa-alueilla on jo tehty. Mutta miten olisi kokonaisesityksen toteuttaminen? Hanke voisi tuottaa sellaisia jatkumoja, joiden varassa voitaisiin suunnistaa myös tulevaisuuteen.

Seitsemäs haaste onkin sitten sangen raadollinen. Kysymys on siitä, miten työväentutkimusta rahoitetaan ja organisoidaan. Kun yliopistot panostavat yhä voimakkaammin kansainväliseen artikkelijulkaisemiseen, on vaarana, että laajempien kokonaisesitysten julkaiseminen vähenee. Tutkijoita tulisi kannustaa myös suomenkieliseen julkaisemiseen, sillä vain näin menetellen tavoitetaan laajoja kohdeyleisöjä. Työväen historian ja perinteen tutkimuksen seuralle ja myös työväenliikkeen järjestöille asettuu oma tehtävänsä tutkimuksen virittämisessä. Erityinen haaste on laajempien tutkimushankkeiden käynnistäminen ja rahoituksen löytäminen niille sekä uuden, aihepiiristä innostuneen tutkijasukupolven kasvattaminen. 